\title{
PENGARUH KOMPENSASI, MOTIVASI DAN DISIPLIN KERJA TERHADAP KINERJA KARYAWAN UNIVERSITAS MURIA KUDUS
}

\author{
Siti Aniqoh Shofwani, Ahmad Hariyadi \\ STIE SEMARANG, IKIP PGRI BOJONEGORO \\ Aniqoh2017@gmail.com, ahmadhariyadi31@yahoo.co.id
}

\begin{abstract}
This study aims to examine the influence of Compensation, Work Motivation and Discipline to Performance Employee in Muria Kudus University.The research was conducted by using survey methods to Employees Administrative in Muria Kudus University and analyzed by using regression analysis. The samples in this study were taken 45 people with a view to facilitate researchers in conducting research. While sampling technique used in this study using purposive sampling technique in which the sample collection elements are included in the sample was done on purpose, provided that the sample is representative or representative of the population. The results showed that the variable compensation, motivation and discipline work simultaneously positive and significant influence on employee performance. This is evidenced by the value (Fhitung $=23.705)>(F$ table $=2.84)$ and the value of [pvalue $($ Sig. $)=0.000)]<0.05$. based this conclusion it is suggested that leaders can manage the three variables toward the repair or improvement of employee performance.
\end{abstract}

Keywords: Compensation, Motivation, Discipline Work, Employee Performance

\begin{abstract}
ABSTRAK
Penelitian ini bertujuan untuk menguji Pengaruh Kompensasi, Motivasi dan Disiplin Kerja terhadap Kinerja Karyawan Administrasi Universitas Muria Kudus. Penelitian ini dilakukan dengan menggunakan metode survey kepada Karyawan Administrasi Universitas Muria Kudus. dan dianalisis dengan menggunakan analisis regresi. Adapun sampel dalam penelitian ini diambil 45 orang dengan pertimbangan untuk memudahkan peneliti dalam melakukan penelitian. Sedangkan Teknik sampel yang digunakan dalam penelitian ini menggunakan teknik purposive sampling yaitu Sampel dimana pengambilan elemen-elemen yang dimasukan dalam sampel dilakukan dengan sengaja, dengan catatan bahwa sampel tersebut representatif atau mewakili populasi. Hasil penelitian menunjukan bahwa variabel kompensasi, motivasi dan disiplin kerja secara simultan berpengaruh positif dan signifikan terhadap kinerja karyawan. Hal ini dibuktikan dengan nilai (Fhitung $=23,705)>($ Ftabel $=$ 2,84) dan nilai [pvalue $($ Sig.) $=0,000)$ ] $<0,05$. berdasarkan kesimpulan tersebut maka disarankan agar pimpinan dapat mengelola ketiga variabel tersebut menuju perbaikan atau peningkatan kinerja karyawan.
\end{abstract}

Kata Kunci : Kompensasi, Motivasi, Disiplin Kerja, Kinerja Karyawan

\section{PENDAHULUAN}

Sumber daya manusia merupakan tokoh sentral dalam organisasi maupun perusahaan. Agar aktivitas manajemen berjalan dengan baik, perusahaan harus memiliki karyawan yang berpengetahuan dan berketrampilan tinggi serta usaha untuk mengelola perusahaan seoptimal mungkin sehingga kinerja karyawan meningkat. 
Menurut Budi Setiyawan dan Waridin (2006) kinerja karyawan merupakan hasil atau prestasi kerja karyawan yang dinilai dari segi kualitas maupun kuantitas berdasarkan standar kerja yang ditentukan oleh pihak organisasi. Brahmasari (2004) mengemukakan bahwa kinerja adalah pencapaian atas tujuan organisasi yang dapat berbentuk output kuantitatif maupun kualitatif, kreatifitas, fleksibilitas, dapat diandalkan, atau hal-hal lain yang diinginkan oleh organisasi.

Kompensasi menurut Malayu S.P. Hasibuan (2002) adalah semua pendapatan yang berbentuk uang, barang langsung atau tidak langsung yang diterima karyawan sebagai imbalan atas jasa yang diberikan kepada perusahaan. Tujuan pemberian kompensasi antara lain adalah sebagai ikatan kerja sama, kepuasan kerja, pengadaan efektif, motivasi, stabilitas karyawan, disiplin, serta pengaruh serikat buruh dan pemerintah. Kompensasi adalah penghargaan atau ganjaran pada para pekerja yang telah memberikan kontribusi dalam mewujudkan tujuannya, melalui kegiatan yang disebut bekerja (Nawawi, 2001).

Motivasi adalah dorongan, upaya dan keinginan yang ada di dalam diri manusia yang mengaktifkan, memberi daya serta mengarahkan perilaku untuk melaksanakan tugas-tugas dengan baik dalam lingkup pekerjaannya (Hakim, 2006). Robbins (2006) mendefinisikan motivasi sebagai proses yang ikut menentukan intensitas, arah, dan ketekunan individu dalam usaha mencapai sasaran. Motivasi sebagai proses yang bermula dari kekuatan dalam hal fisiologis dan psikologis atau kebutuhan yang mengakibatkan perilaku atau dorongan yang ditujukan pada sebuah tujuan atau insentif (Moekijat, 2001 dalam Hakim, 2006).

Disiplin adalah taat kepada hukum dan peraturan yang berlaku. Jadi, disiplin karyawan adalah kegiatan karyawan yang bersangkutan dalam menghormati perjanjian kerja dengan organisasi di mana dia bekerja (Prawirosentono, 1999). Menurut Budi Setiyawan dan Waridin (2006) disiplin sebagai keadaan ideal dalam mendukung pelaksanaan tugas sesuai aturan dalam rangka mendukung optimalisasi kerja.

Sebagai sebuah lembaga perguruan tinggi, Universitas Muria Kudus. selalu berupaya untuk meningkatkan mutu pendidikan dan reputasinya. Namun dalam upaya menciptakan kinerja

karyawan Universitas Muria Kudus. nampaknya masih terdapat banyak kendala yang dihadapi sehingga sulit untuk mencapai tujuan organisasi.

Faktor pertama yang diindikasikan menyebabkan rendahnya kinerja adalah faktor kompensasi. Sedangkan faktor yang kedua adalah faktor motivasi. Motivasi kerja adalah keinginan untuk melakukan sebagai kesediaan untuk mengeluarkan tingkat upaya yang tinggi untuk tujuan-tujuan organisasi, yang dikondisikan oleh kemampuan upaya itu untuk 
memenuhi suatu kebutuhan individual (Robbin dalam Brahmasari, 2008:125). Faktor- faktor yang meningkatkan motivasi antara lain kebutuhan dan kepuasan individu.

Data tersebut menunjukkan bahwa tingkat ketidakhadiran karyawan dari bulan Januari sampai bulan Desember 2011 mengalami peningkatan. Dari segi ini terlihat bahwa kedisiplinan dan tanggung jawab karyawan di Universitas Wahid Hasyim Semarang dirasa kurang optimal, sehingga berdampak pada kinerja karyawan yang belum sesuai dengan yang diharapkan.

Berdasarkan fenomena sosial yang terjadi pada organisasi tersebut maka penelitian ini mengambil judul "Pengaruh Kompensasi, Motivasi dan Disiplin Kerja terhadap Kinerja Karyawan Universitas Muria Kudus”.

\section{MASALAH PENELITIAN}

a) Apakah terdapat Pengaruh positif dan signifikan antara Kompensasi terhadap Kinerja karyawan Universitas Muria Kudus ?

b) Apakah terdapat Pengaruh yang positif antara Motivasi terhadap Kinerja karyawan Universitas Muria Kudus?

c) Apakah terdapat Pengaruh positif dan signifikan antara disiplin terhadap Kinerja karyawan Universitas Muria Kudus?

d) Apakah terdapat Pengaruh positif dan signifikan antara motivasi, kompensasi dan disiplin terhadap Kinerja karyawan Universitas Muria Kudus?

\section{KAJIAN TEORITIS}

Kinerja Karyawan

Kinerja adalah kandisi dari sebuah kelompok di mana ada tujuan yang jelas dan tetap yang dirasakan menjadi penting dan terpadu dengan tujuan individu (Panggabean, 2004:21). Menurut Pabundu Tika (2008:121), kinerja adalah hasil fungsi pekerjaan/kegiatan seseorang atau kelompok dalam suatu organisasi yang dipengaruhi oleh berbagai faktor untuk mencapai tujuan organisasi dalam periode waktu tertentu. .

Pegawai yang mempunyai kinerja tinggi, maka pekerjaan akan lebih cepat diselesaikan, kerusakan akan dapat dikurangi, absensi akan dapat diperkecil, kemungkinan perpindahan pegawai dapat diperkecil seminimal mungkin. Hal ini semua berarti diharapkan bukan saja produktivitas kerja dapat ditingkatkan, tetapi biaya yang dikeluarkan juga menjadi sedikit (Nitisemito, 2002:160). 
Menurut Panggabean (2004:21), beberapa faktor yang dapat mempengaruhi kinerja pegawai adalah :

1) Kondisi pekerjaan

2) Rekan kerja

3) Kompensasi

4) Kepemimpinan

5) Perusahaan

6) Lingkungan Kerja

Kompensasi

Definisi kompensasi menurut Mutiara S. Panggabean (2004:75) mengemukakan: "Kompensasi dapat didefinisikan sebagai setiap bentuk penghargaan yang diberikan kepada karyawan sebagai balas jasa atas kontribusi yang mereka berikan kepada organisasi”.

Menurut Veithzal Rivai (2004:357) Mengemukakan bahwa: “Kompensasi merupakan sesuatu yang diterima karyawan sebagai pengganti kontribusi jasa mereka pada perusahaan”.

Berdasarkan pengertian-pengertian diatas maka peneliti mencoba menyimpulkan bahwa kompensasi merupakan bentuk penghargaan atau balas jasa yang diberikan oleh perusahaan kepada karyawannya baik yang berbentuk finansial maupun barang dan jasa pelayanan agar karyawan merasa dihargai dalam bekerja. Pemberian kompensasi merupakan salah satu pelaksanaan fungsi MSDM yang berhubngan dengan semua jenis pemberian penghargaan individual sebagai pertukaran dalam melakukan tugas organisasian.

Menurut Veithzal Rivai (2004 : 358) kompensasi terbagi menjadi dua yaitu sebagai berikut :

1. Kompensasi Finansial,

2. Kompensasi Non Finansial.

Menurut Anwar Prabu Mangkunegara (2007:84) ada enam faktor yang mempengaruhi kebijakan kompensasi yaitu :
a. Faktor Pemerintah
b. Penawaran Bersama antara Perusahaan dan Pegawai
c. Standard Biaya Hidup Pegawai
d. Ukuran Perbandingan Upah
e. Permintaan dan Persediaan
f. Kemampuan Membayar 
Menurut Veithzal Rivai (2004:366) Tujuan manajemen kompensasi bukanlah membuat berbagai aturan dan hanya memberikan petunjuk saja. Namun, semakin banyak tujuan perusahaan dan tujuan pemberian kompensasi juga harus diikuti dengan semakin efektif administrasi penggajian dan pengupahan. Untuk memenuhi tujuan-tujuan tersebut, perlu diikuti tahapan-tahapan manajemen kompensasi sebagai berikut ini:

Tahap 1 : Mengevaluasi tiap pekerjaan, dengan menggunakan informasi analisis pekerjaan, untuk menjamin keadilan internal yang didasarkan pada nilai relative setiap pekerjaan

Tahap 2 : Melakukan survey upah dan gaji untuk menentukan keadilan eksternal yang didasarkan pada upah pembayaran dipasar kerja.

Tahap 3 : Menilai harga tiap pekerjaan untuk menentukan pembayaran upah yang didasarkan pada keadilan internal dan eksternal.

Menurut Mutiara S. Panggabean (2004:83) metode penetapan gaji yang serasional apapun akan menghadapi tantangan-tantangan tersebut adalah sebagai berikut :
a. Standar gaji yang berlaku umum
b. Kekuatan serikat buruh
c. Produktivitas
d. Kebijaksanaan gaji dan upah
e. Peraturan pemerintah
f. Nilai yang sebanding dengan pembayaran yang sama

\section{Motivasi}

Menurut Ishak Arep (2004:12) Pengertian Motivasi adalah sesuatu yang pokok yang menjadikan dorongan bagi seseorang untuk bekerja. Motivasi menurut Malayu S.P Hasibuan (2008:95) adalah pemberian daya penggerak yang menciptakan kegairahan kerja seseorang agar mereka mampu bekerjasama, bekerja efektif dan terintegrasi dengan segala daya upayanya untuk mencapai kepuasan. Sedangkan pengertian Motivasi menurut Manullang (2001:146) berarti pemberian tenaga pendorong yang mendorong manusia untuk bertindak atau suatu tenaga di dalam diri manusia yang menyebabkan manusia bertindak.

Ciri-ciri pegawai yang memiliki motivasi menurut Manullang (2001:148) antara lain di antaranya : bekerja sesuai standar, senang bekerja, merasa berharga, bekerja keras, sedikit pengawasan, semangat tinggi, tidak banyak komplain, tidak mudah mengeluh, tidak mudah menyerah, taat pada perintah atasan tidak banyak beristirahat dalam bekerja. 
Menurut Ravianto dalam Manajemen Kepegawaian (2002:66) bahwa kebutuhan manusia yang menjadi sumber motivasi untuk berperilaku terdiri atas :

a. Kebutuhan dasar fisiologis atau kebutuhan primer

b. Kebutuhan sekunder

\section{Disiplin Kerja}

Secara etimologi, disiplin berasal dari bahasa latin "disipel" yang berarti pengikut. Seiring dengan perkembangan jaman, kata tersebut mengalami perubahan menjadi "disipline" yang artinya kepatuhan atau yang menyangkut tata tertib. Disiplin kerja menurut Wursanto (2001 : 147) adalah suatu sikap ketaatan seseorang terhadap aturan / ketentuan yang berlaku dalam organisasi,yaitu: menggabungkan diri dalam organisasi itu atas dasar keinsafan, bukan unsur paksaan.

M. Sinungan (2001:135) mendefinisikan Disiplin adalah sikap dari seseorang/kelompok orang yang senantiasa berkehendak untuk mengikuti/mematuhi segala aturan/keputusan yang ditetapkan.. Disiplin kerja adalah sikap mental yang tercermin dalam perbuatan atau tingkah laku seseorang, kelompok masyarakat berupa ketaatan (obedience) terhadap peraturan, norma yang berlaku dalam masyrarakat. ( Siagian $2002: 145$ ).

Menurut Abdurrahmat Fathoni (2006 : 126) disiplin diartikan sebagai kesadaran dan kesediaan seseorang mentaati semua peraturan dan norma norma social yang berlaku.

Dari beberapa pendapat itu dapat disimpulkan bahwa disiplin kerja adalah sikap ketaatan dan kesetiaan seseorang / sekelompok orang terhadap peraturan tertulis / tidak tertulis yang tercermin dalam bentuk tingkah laku dan perbuatan pada suatu organisasi untuk mencapai suatu tujuan tertentu.

Tujuan disiplin baik kolektif maupun perorangan yang sebenarnya adalah untuk mengarahkan tingkah laku pada realita yang harmonis. Untuk menciptakan kondisi tersebut, terlebih dahulu harus di wujudkan keselerasan antara hak dan kewajiban pegawai/karyawan.

Tipe-tipe kegiatan pendisiplinan ada tiga-tipe, yaitu :

\section{Disiplin preventif}

2. Disiplin korektif

3. Disiplin progresif (T. Hani Handoko, 2003 : 129-130).

Untuk mengkondisikan pegawai agar bersikap disiplin, maka dikemukakan prinsip pendisiplinan sebagai berikut:

1. Pendisiplinan dilakukan secara pribadi. 
2. Pendisiplinan yang bersifat membangun.

3. Keadilan dalam pendisiplinan.

4. Pendisiplinan dilakukan pada waktu karyawan tidak absen.

5. Setelah pendisiplinan hendaknya dapat bersikap wajar.

Hubungan antara Kompensasi terhadap Kinerja

Dalam Tika (2006:139) menyatakan kompensasi dapat mempunyai dampak yang berarti dalam kinerja organisasi jangka panjang. kompensasi mungkin akan menjadi suatu faktor yang bahkan lebih penting lagi dalam menentukan keberhasilan organisasi. Dalam Handoko (2003:58) menyatakan bahwa kompensasi yang tinggi sering dikatakan membantu kinerja karena menciptakan suatu motivasi yang luar biasa dalam diri pegawai. Dari beberapa pendapat dan hasil penelitian yang telah dipaparkan, dapat disimpulkan bahwa kompensasi mempunyai pengaruh terhadap peningkatan kinerja pegawai dalam organisasi demi tercapainya tujuan organisasi.

Berdasarkan uraian di muka, maka dapat dibuat hipotesis dalam penelitian ini adalah sebagai berikut :

H1: Kompensasi berpengaruh positif terhadap kinerja karyawan.

Hubungan antara Motivasi terhadap Kinerja

Suharto dan Cahyono (2005) dan Hakim (2006) menyebutkan ada salah satu faktor yang mempengaruhi kinerja yaitu faktor motivasi, dimana motivasi merupakan kondisi yang menggerakan seseorang berusaha untuk mencapai tujuan atau mencapai hasil yang diinginkan. Rivai (2004) menunjukan bahwa semakin kuat motivasi kerja, kinerja pegawai akan semakin tinggi. Hal ini berarti bahwa setiap peningkatan motivasi kerja pegawai akan memberikan peningkatan yang sangat berarti bagi peningkatan kinerja pegawai dalam melaksanakan pekerjaannya.

Berdasarkan uraian di muka, maka dapat dibuat hipotesis dalam penelitian ini adalah sebagai berikut :

H2: Motivasi berpengaruh positif terhadap kinerja karyawan.

Hubungan antara Disiplin kerja terhadap Kinerja

Menurut Setiyawan dan Waridin (2006) dan Aritonang (2005) menyatakan bahwa disiplin kerja karyawan bagian dari faktor kinerja. Disiplin kerja harus dimiliki setiap karyawan dan harus dibudayakan di kalangan karyawan agar bisa mendukung tercapainya 
tujuan organisasi karena merupakan wujud dari kepatuhan terhadap aturan kerja dan juga sebagai tanggung jawab diri terhadap perusahaan. Pelaksanaan disiplin dengan dilandasi kesadaran dan keinsafan akan terciptanya suatu kondisi yang harmonis antara keinginan dan kenyataan. Untuk menciptakan kondisi yang harmonis tersebut terlebih dahulu harus diwujudkan keselarasan antara kewajiban dan hak karyawan. Sehingga dapat disimpulkan bahwa disiplin merupakan sikap kesetiaan dan ketaatan seseorang atau sekelompok orang terhadap peraturan peraturan baik tertulis maupun tidak tertulis, yang tercermin dalam bentuk tingkah laku dan perbuatan.

Berdasarkan uraian di muka, maka dapat dibuat hipotesis dalam penelitian ini adalah sebagai berikut :

H3: Disiplin kerja berpengaruh positif terhadap kinerja karyawan.

\section{Kerangka Pemikiran}

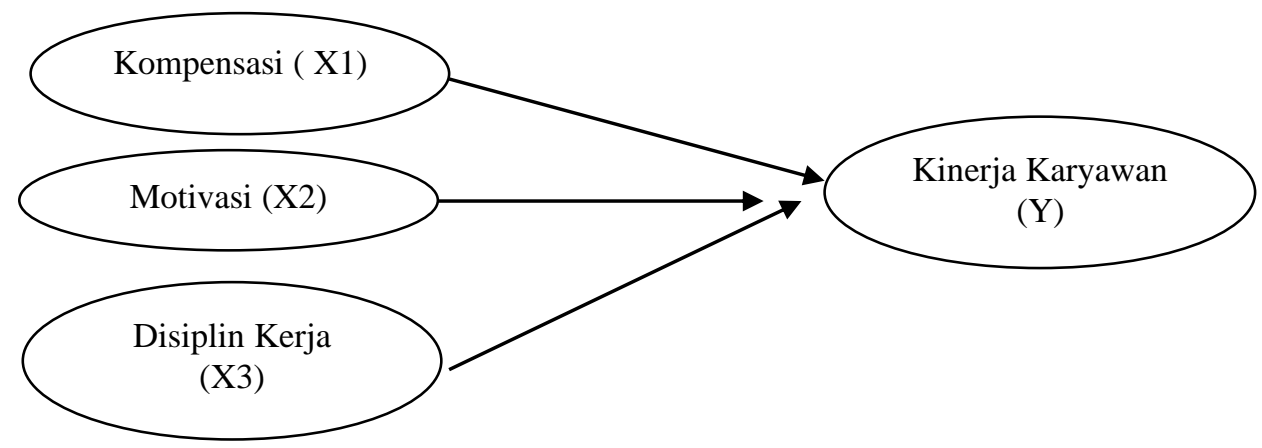

Hipotesis

H1 : Kompensasi berpengaruh secara positif terhadap Kinerja Karyawan.

H2 : Motivasi berpengaruh secara positif terhadap Kinerja Karyawan.

H3 : Disiplin Kerja berpengaruh positif terhadap Kinerja Karyawan.

Variabel Penelitian

Variabel independen (bebas) dalam penelitian ini adalah Kompensasi (X1), Motivasi (X2), Disiplin Kerja (X3). Sedangkan variable dependen (terikat) dalam penelitian ini adalah Kinerja Karyawan (Y).

Unit Sampel

Dalam penelitian ini pengambilan sampel yang akan digunakan adalah karyawan pada Universitas Wahid Hasyim Semarang yang berjumlah 83 orang. Setelah dihitung dengan rumus Slovin sehingga menjadi 45 orang karyawan pada Universitas Muria Kudus.

Populasi

Adapun Jumlah populasi dalam penelitian ini sebanyak 83 orang. 


\section{METODOLOGI}

Dalam penelitian ini untuk mengolah data dari hasil penelitian dengan menggunakan Analisis Inferensial (kuantitatif).

Adapun langkah langkah yang harus dilakukan dalam metode analisis adalah sebagai berikut :

1. Uji Validitas

2. Uji Reliabilitas

3. Uji Asumsi Klasik

1) Uji Normalitas

2) Uji Multikolinearitas

3) Uji Heterokedastisitas

4. Analisis Regresi

5. Uji Hipotesis ( Uji t )

6. Uji F

\section{Pembahasan}

1. Tabel Hasil Uji Validitas

\begin{tabular}{|c|c|c|c|c|c|}
\hline \multicolumn{2}{|c|}{ Variabel } & \multicolumn{2}{|l|}{$\mathrm{r}_{\text {hitung }}$} & \multirow{2}{*}{$\begin{array}{l}\mathbf{r} \text { tabel } \\
0,301\end{array}$} & \multirow{2}{*}{$\begin{array}{c}\text { Keterangan } \\
\text { Valid }\end{array}$} \\
\hline \multirow{4}{*}{$\begin{array}{l}\text { Kompensasi } \\
\left(\mathrm{X}_{1}\right)\end{array}$} & $\mathrm{X}_{1.1}$ & 0,647 & $>$ & & \\
\hline & $\mathrm{X}_{1.2}$ & 0,711 & $>$ & 0,301 & Valid \\
\hline & $\mathrm{X}_{1.3}$ & 0,330 & $>$ & 0,301 & Valid \\
\hline & $\mathrm{X}_{1.4}$ & 0,432 & $>$ & 0,301 & Valid \\
\hline \multirow{4}{*}{$\begin{array}{l}\text { Motivasi } \\
\qquad\left(\mathrm{X}_{2}\right)\end{array}$} & $\mathrm{X}_{2.1}$ & 0,622 & $>$ & 0,301 & Valid \\
\hline & $\mathrm{X}_{2.2}$ & 0,490 & $>$ & 0,301 & Valid \\
\hline & $\mathrm{X}_{2.3}$ & 0,460 & $>$ & 0,301 & Valid \\
\hline & $\mathrm{X}_{2.4}$ & 0,613 & $>$ & 0,301 & Valid \\
\hline \multirow{4}{*}{$\begin{array}{l}\text { Disiplin Kerja } \\
\qquad\left(\mathrm{X}_{3}\right)\end{array}$} & $\mathrm{X}_{3.1}$ & 0,332 & $>$ & 0,301 & Valid \\
\hline & $\mathrm{X}_{3.2}$ & 0,439 & $>$ & 0,301 & Valid \\
\hline & $\mathrm{X}_{3.3}$ & 0,450 & $>$ & 0,301 & Valid \\
\hline & $\mathrm{X}_{3.4}$ & 0,384 & $>$ & 0,301 & Valid \\
\hline \multirow{4}{*}{$\begin{array}{c}\text { Kinerja } \\
\text { Karyawan } \\
\text { (Y) }\end{array}$} & $\mathrm{Y}_{1}$ & 0,564 & $>$ & 0,301 & Valid \\
\hline & $\mathrm{Y}_{2}$ & 0,567 & $>$ & 0,301 & Valid \\
\hline & $\mathrm{Y}_{3}$ & 0,776 & $>$ & 0,301 & Valid \\
\hline & $\mathrm{Y}_{4}$ & 0,739 & $>$ & 0,301 & Valid \\
\hline
\end{tabular}

Berdasarkan tabel hasil uji validitas dapat diketahui bahwa semua item pertanyaan/indikator variabel kompensasi, motivasi, disiplin kerja dan kinerja karyawan dinyatakan valid karena dari hasil korelasi antara hasil jawaban responden pada tiap item pertanyaan/indikator dengan skor total di dapat hasil yang signifikan, yaitu nilai $r_{\text {hitung }}>r_{\text {tabel }}$. 
2. Tabel Hasil Uji Reliabilitas

\begin{tabular}{l|c|c}
\hline \multicolumn{1}{c|}{ Variabel } & Cronbach's Alpha & Keterangan \\
\hline Kompensasi & $0,727>0,600$ & Reliabel \\
Motivasi & $0,749>0,600$ & Reliabel \\
Disiplin Kerja & $0,621>0,600$ & Reliabel \\
Kinerja Karyawan & $0,831>0,600$ & Reliabel \\
\hline
\end{tabular}

Hasil uji reliabilitas memperlihatkan nilai Cronbach's Alpha semua variabel di atas 0,60, sehingga dapat disimpulkan bahwa indikator yang digunakan oleh variabel kompensasi, motivasi, disiplin kerja dan kinerja karyawan dapat dipercaya atau handal untuk digunakan sebagai alat ukur variabel.

3. Tabel Hasill Uji Kolmogorov-Smirnov

One-Sample Kolmogorov-Smirnov Test

\begin{tabular}{|ll|r|r|r|r|}
\hline & & Kompensasi & Motivasi & Disiplin Keria & \multicolumn{1}{c|}{ Kineria } \\
\hline $\mathrm{N}$ & & 45 & 45 & 45 & 45 \\
Normal Parameters ${ }^{\mathrm{a}, \mathrm{b}}$ & Mean & 14.91 & 15.04 & 15.16 & 14.91 \\
& Std. Deviation & 2.334 & 2.163 & 2.088 & 2.485 \\
Most Extreme & Absolute & .174 & .159 & .121 & .154 \\
Differences & Positive & .174 & .152 & .121 & .154 \\
& Negative & -.095 & .159 & -.091 & -.098 \\
Kolmogorov-Smirnov Z & & 1.165 & 1.067 & .810 & 1.034 \\
Asymp. Sig. (2-tailed) & & .132 & .205 & .528 & .235 \\
\hline
\end{tabular}

a. Test distribution is Normal.

b. Calculated from data.

Tabel 4.6 menunjukkan bahwa nilai $\mathrm{p}_{\text {value }}$ (Asymp.Sig.) dari semua variabel adalah > 0,05 . Oleh karena itu dapat disimpulkan bahwa data yang digunakan dalam penelitian ini berdistribusi normal.

2) Tabel Hasil Uji Multikolineritas

Coefficients $^{a}$

\begin{tabular}{|ll|r|c|}
\hline \multirow{2}{*}{ Model } & \multicolumn{2}{|c|}{ Collinearity Statistics } \\
\cline { 3 - 4 } & & Tolerance & \multicolumn{1}{c|}{ VIF } \\
\hline 1 & Kompensasi & .424 & 2.356 \\
& Motivasi & .464 & 2.154 \\
& Disiplin Kerja & .766 & 1.305 \\
\hline
\end{tabular}

a. Dependent Variable: Kinerja

Berdasarkan hasil pengujian multikolinearitas menunjukkan bahwa antar variabel independen (kompensasi, motivasi dan disiplin kerja) semuanya tidak terjadi 
multikolinearitas, karena nilai tolerance masing-masing variabel independen berada di atas 0,1 dan nilai VIF masing-masing variabel independen berada di bawah 10

Gambar Hasil Uji Heteroskedastisitas (Grafik Scatter Plot)

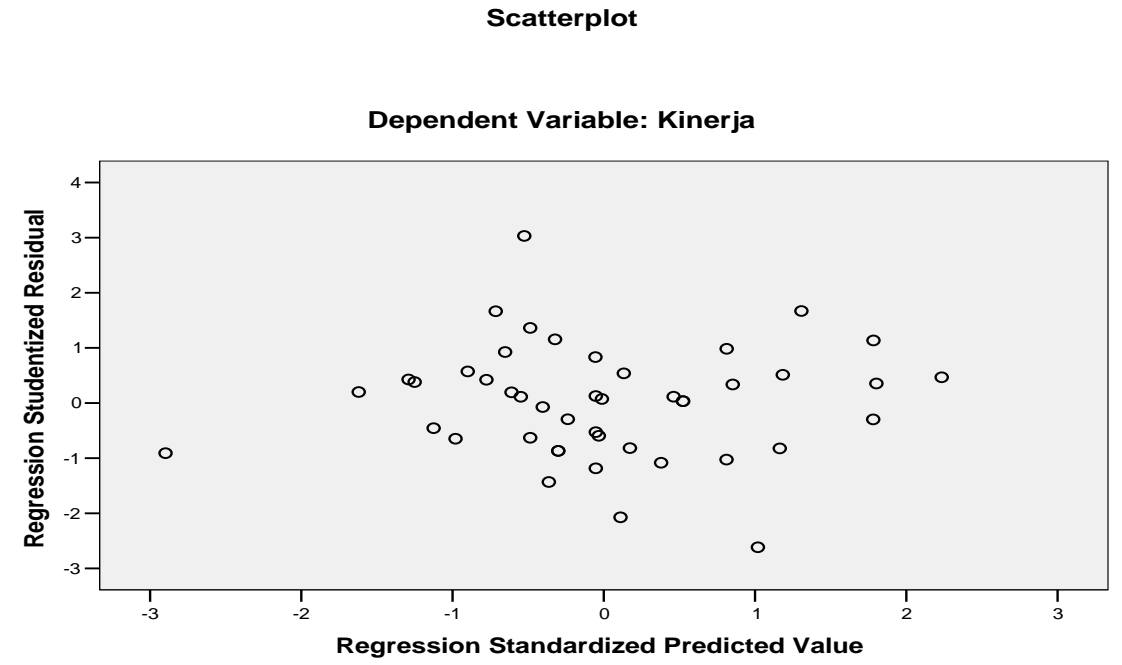

Grafik scatter plots pada Gambar memperlihatkan bahwa titik-titik pada grafik tidak bisa membentuk pola tertentu yang jelas, dimana titik-titik menyebar di atas dan di bawah angka 0 pada sumbu Y, sehingga grafik tersebut tidak bisa dibaca dengan jelas. Hasil ini memperlihatkan bahwa tidak terjadi heteroskedastisitas.

4. Tabel Hasil Analisis Regresi Linier Berganda

Coefficients $^{\mathrm{a}}$

\begin{tabular}{|rl|r|r|r|r|r|}
\hline \multirow{2}{*}{ Model } & \multicolumn{2}{|c|}{$\begin{array}{c}\text { Unstandardized } \\
\text { Coefficients }\end{array}$} & \multicolumn{2}{c|}{$\begin{array}{c}\text { Standardized } \\
\text { Coefficients }\end{array}$} & \\
\cline { 2 - 5 } & \multicolumn{1}{|c|}{$\mathrm{B}$} & \multicolumn{1}{c|}{ Std. Error } & \multicolumn{1}{c|}{ Beta } & \multicolumn{1}{c|}{$\mathrm{t}$} & Sig. \\
\hline 1 & (Constant) & -1.025 & 2.013 & & -.509 & .614 \\
& Kompensasi & .408 & .154 & .384 & 2.646 & .011 \\
& Motivasi & .366 & .159 & .319 & 2.301 & .027 \\
& Disiplin Kerja & .286 & .128 & .240 & 2.228 & .031 \\
\hline
\end{tabular}

a. Dependent Variable: Kinerja

Berdasarkan hasil analisis regresi linier berganda yang didapat maka dibuat persamaan liniear berganda sebagai berikut:

$$
Y=0,384 X_{1}+0,319 X_{2}+0,240 X_{3}
$$

5. Tabel Hasil Uji $-\mathrm{t}$

\begin{tabular}{|c|c|c|c|c|c|c|}
\hline Variabel & $\mathbf{t}$ hitung & $\begin{array}{l}>1 \\
<\end{array}$ & $\mathbf{t}$ tabel & $\begin{array}{c}\text { Sig. } \\
\text { (pvalue) }\end{array}$ & $\begin{array}{c}\text { Keput } \\
\text { usan }\end{array}$ & Keterangan \\
\hline Kompensasi $\left(\mathrm{X}_{1}\right)$ & 2,646 & $>$ & 2,020 & $0,011<0,05$ & Ho ditolak & Signifikan \\
\hline Motivasi $\left(\mathrm{X}_{2}\right)$ & 2,301 & $>$ & 2,020 & $0,027<0,05$ & Ho ditolak & Signifikan \\
\hline Disiplin Kerja (X3) & 2,228 & $>$ & 2,020 & $0,031<0,05$ & Ho ditolak & Signifikan \\
\hline
\end{tabular}


a) Pengaruh kompensasi terhadap kinerja karyawan didapat $t_{\text {hitung }}=2,646$ dengan sig. 0,011, karena nilai sig. yang di dapat < tingkat sign. $\mathrm{a}=0,05$, maka Ho ditolak dan Ha diterima.

b) Pengaruh motivasi terhadap kinerja karyawan didapat $\mathrm{t}$ hitung $=2,301$ dengan sig. 0,027, karena nilai sig. yang di dapat $<$ tingkat sign. $a=0,05$, maka Ho ditolak dan Ha diterima.

c) Pengaruh disiplin kerja terhadap kinerja karyawan didapat $t$ hitung $=2,228$ dengan sig. 0,031, karena nilai sig. yang di dapat $<$ tingkat sign. $\mathrm{a}=0,05$, maka Ho ditolak dan Ha diterima.

\section{Tabel Hasil Uji-F}

\section{ANOVA}

\begin{tabular}{|c|c|c|c|c|c|c|}
\hline \multicolumn{2}{|c|}{ Model } & $\begin{array}{l}\text { Sum of } \\
\text { Squares }\end{array}$ & df & Mean Square & $\mathrm{F}$ & Sig. \\
\hline \multirow[t]{3}{*}{1} & Regression & 172.305 & 3 & 57.435 & 23.705 & $.000^{a}$ \\
\hline & Residual & 99.340 & 41 & 2.423 & & \\
\hline & Total & 271.644 & 44 & & & \\
\hline
\end{tabular}

a. Predictors: (Constant), Disiplin Kerja, Motivasi, Kompensasi

b. Dependent Variable: Kinerja

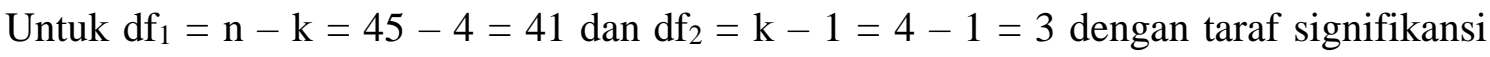
0,05 , diperoleh harga kritis $F\left(F_{\text {tabel }}=2,79\right)$. Karena $\left(F_{\text {hitung }}=23,705\right)>\left(F_{\text {tabel }}=2,84\right)$ dan nilai $\left[p_{\text {value }}(\right.$ Sig. $\left.\left.)=0,000\right)\right]<0,05$, sehingga hasil uji-F pada tabel tersebut adalah "signifikan".

\section{KESIMPULAN}

1) Terdapat pengaruh positif dan signifikan dari variabel Kompensasi $\left(\mathrm{X}_{1}\right)$ terhadap Kinerja Karyawan (Y).

2) Terdapat pengaruh positif dan signifikan dari variabel Motivasi (X2) terhadap Kinerja Karyawan (Y).

3) Terdapat pengaruh positif dan signifikan dari variabel Disiplin Kerja (X3) terhadap Kinerja Karyawan (Y).

4) Variabel -variabel kompensasi, motivasi dan disiplin kerja dalam pekerjaan secara bersama-sama/simultan berpengaruh positif dan signifikan terhadap kinerja karyawan. 


\section{DAFTAR PUSTAKA}

Abdurrahmat Fathoni, 2006, Manajemen Sumber Daya Manusia, Bandung : Rineka. Cipta.

Alex S, Nitisemito, 2002, Manajemen Personalia. Cetakan ke 9. Jakarta: Ghalia Indonesia. Arep, Ishak dan Hendri Tanjung. 2004. Manajemen Motivasi. Jakarta. PT. Grasindo.

Aritonang Lerbin R. 2005. Kepuasan Pelanggan. Jakarta: PT Gramedia Pustaka.

Brahmasari Ida Ayu, 2004. Pengaruh Variabel Budaya Perusahaan terhadap Komitmen Karyawan dan Kinerja Perusahaan Kelompok penerbitan Pers Jawa pos, Disertai Universitas Airlangga Surabaya.

Brahmasari, Ida Ayu dan Agus Suprayetno. 2008. Pengaruh Motivasi Kerja, Kepemimpinan, dan Budaya Organisasi Terhadap Kepuasan Kerja Karyawan serta Dampaknya pada Kinerja Perusahaan (Studi kasus pada PT. Pei Hei International Wiratama Indonesia). Jurnal Manajemen dan Kewirausahaan. Vol. 10, September: 124-135.

Cahyono, Budhi dan Suharto, 2005, Pengaruh Budaya Organisasi, Kepemimpinan dan Motivasi Kerja Terhadap Kinerja Sumber Daya Manusia Di Sekretariat DPRD Propinsi Jawa Tengah, jurnal, JRBI Vol. 1, Yogyakarta

Hakim, Abdul. 2006. Analisis Pengaruh Motivasi, Komitmen Organisasi dan Iklim Organisasi terhadap Kinerja Pegawai pada Dinas Perhubungan dan Telekomunikasi Provinsi Jawa Tengah. JRBI. Vol.2 No. 2. Hal : 165-180.

Handoko, T.Hani, 2003, Manajemen Personalia dan Sumber Daya Manusia,. Yogyakarta: BPFE-Yogyakarta.

Hasibuan, Malayu. 2004. Manajemen Sumber Daya Manusia. PT Bumi Aksara. Jakarta.

Hasibuan, Malayu. 2008. Manajemen Dasar, Pengertian, Dan Masalah. Jakarta: PT Bumi Aksara.

Mangkunegara, 2001. Manajemen Sumber Daya Manusia. Jakarta: Bumi Aksara.

Marihot, Manullang. 2001. Manajemen Sumber Daya Manusia. Yogyakarta: BPFE.

Moekijat, Drs, 2001. Dasar - Dasar Motivasi. Bandung : Pionir Jaya.

Nawawi, Hadari. 2001. Manajemen Sumber Daya Manusia untuk Bisnis yang Kompetitif. Cetakan Keempat. Yogyakarta : Penerbit Gadjah Mada University Press.

Panggabean, S., Mutiara. 2004. Manajemen Sumber Daya Manusia. Bogor: Ghalia Indonesia.

Prawirosentono.S, 1999. Manajemen Sumber Daya Manausia, Kebijakan Kinerja Karyawan. Yogyakarta : BPFE.

Rivai, Veithzal. 2005. Manajemen Sumber Daya Manusia Untuk Perusahaan. Jakarta : PT Rajagrafindo Persada. 
Robbins, Stephen. P. dan Mary Coulter. 2006. Manajemen. Jakarta : PT INDEKS Kelompok Gramedia.

Setiyawan, Budi Waridin. 2006. Pengaruh Disiplin Kerja Karyawan dan Budaya Organisasi terhadap Kinerja di Divisi Radiologi RSUP Dokter Kariadi Semarang. JRBI. Vol 2 No 2. Hal : $181-198$.

Siagian, Sondong. P. 2002. Kiat Meningkatkan Produktivitas Kerja. PT Rineka Cipta. Jakarta.

Sinungan, Muchdarsyah. 20031. Produktivitas Apa dan Bagaimana. Bandung: Bumi Aksara.

Tika, P. (2006). Budaya Organisasi Dan Peningkatan Kinerja Perusahaan. PT Bumi Aksara. Jakarta.

Tika, P. (2006). Budaya Organisasi Dan Peningkatan Kinerja Perusahaan. PT. Bumi Aksara. Jakarta.

Veithzal Rivai, 2004, Manajemen Sumber Daya Manusia Untuk. Perusahaan, Cetakan Pertama, Jakarta, PT. Raja Grafindo Persada. 